\title{
RELATIONSHIP BETWEEN LIFE EXPECTANCY AND TREATMENT OPTION FOR SMALL CELL LUNG CANCER
}

\author{
Fokeev S.D. ${ }^{1}$, Shoykhet Y.N. ${ }^{1,2}$, Kapitulin S.Yu. ${ }^{1}$, Kazantseva E.S. ${ }^{1}$, Belokrylova Yu.G. ${ }^{1}$, \\ Medvedev A.A. ${ }^{1}$, Zhelkombaeva M.A.1
}

${ }^{1}$ FSBEI «Altai state medical University» Ministry Of Health Of Russia, Barnaul, e-mail: okeev.sergey@yandex.ru; ${ }^{2}$ FSBI «Russian oncological scientific center named. N. N. Blokhin» Ministry Of Health Of Russia, Barnaul, e-mail: starok100@mail.ru

Aims.

To study the life expectancy of patients with small cell lung cancer, depending on the method of treatment; to determine the efficacy of surgical component at the treatment stages of small cell lung cancer and preoperative chemotherapy

Materials and methods.

The study involved 852 patients with small cell lung cancer. All patients were subdivided into 3 groups.

I. Untreated - $155(18.2 \%)$ patients who refused or who were denied treatment due to medical indications.

II. Conservative treatment $-558(65.5 \%)$ patients who received chemoradiotherapy.

III. Surgical treatment $-139(16.3 \%)$ patients, including:

1- 1st subgroup - surgery (without mediastinal lymph node dissection) - in $31(3.6 \%)$;

2- 2nd subgroup - surgery (without mediastinal lymph node dissection), 4 courses of postoperative polychemotherapy and external beam radiotherapy - in $81(9.5 \%)$;

3- 3rd subgroup - 3-4 courses of preoperative polychemotherapy, surgery with mediastinal lymph node dissection, postoperative polychemotherapy $2-4$ courses - in $27(3.1 \%)$.

Among the patients there were $809(94.9 \%)$ men and $43(5.1 \%)$ women. The predominating groups were patients aged: $50-59$ years -249 persons $(29.2 \%)$ and $60-69$ years -314 patients $(36.8 \%)$. The largest number of patients were in stage IIIA (299 persons, $35.1 \%$ ), and a slightly smaller number of patients with stage IIIB (194 persons, 22.7\%)

Results.

The use of surgical treatment of small cell lung cancer has a positive effect on the average life expectancy in patients of group III - $\mathbf{2 6 . 4}$ months, which is longer than in group II by $\mathbf{1 9 . 6}$ and group I - by 24.2 months.

The size of the primary lung tumour starts affecting the average life expectancy of patients with tumour process T1-2, and metastases to regional lymph nodes - with tumour process T2-3N1-2.

Conclusions.

Removal of primary malignant tumour with mediastinal lymph node dissection followed by adjuvant polychemotherapy with modern drugs has a positive effect on the survival of patients.

Keywords: small cell lung cancer, treatment, life expectancy.

\section{INTRODUCTION}

Small-cell lung carcinoma (SCLC) is a highly aggressive primary disseminated malignant tumor with quick double volume increase (on average, 33 days) and early metastasis. The unfavorable clinical prognosis for this disease provided grounds for the classification of small-cell carcinoma into a separate group [1].

Unsatisfactory results of treatment associated with tumor resistance to antitumor drugs made researchers study different chemotherapy plans with new drugs and indicate drugs in high doses with further bone marrow transplantation [2].

During the past decade, new diagnostic medical technology and chemotherapy drugs were introduced for the treatment of malignant tumors. Oncologists that treat lung cancer looked into the 
problem of lung cancer therapy from a different point of view reconsidering the role of surgery in the treatment of this group of patients [3].

The medical society has a positive attitude toward the resection of the primary tumor with mediastinal lymph node dissection with further adjuvant polychemotherapy with modern drugs because it favorably influences the life expectancy of patients [4].

The analysis of surgical treatment for SCLC showed its effectiveness in patients with a local primary process in the lungs (T1-2, N1-2) in combination with 4 courses of polychemotherapy in the early postoperative period. Such complex treatment provided 5-year survival in 10-50\% of patients $[5,6]$.

Radical resection of the primary tumor of lungs together with regional lymph nodes $[7,8]$ provides "complete remission" and allows oncologists to exclude postoperative mediastinum radiotherapy from the treatment plan [9].

Indication of preoperative polychemotherapy to patients with SCLC is aimed at achieving maximum effect (complete tumor regression). The resected primary tumor allows doctors to study the pathomorphological resorption and evaluate the effectiveness of the performed neoadjuvant chemotherapy. The most favorable prognostic factor that directly affects the survival of patients is the complete resection of the tumor. Incomplete resection of the tumor requires the indication of chemotherapy with reserve-line drugs in the postoperative period [10].

The study was aimed to evaluate the life expectancy of patients with small-cell lung carcinoma depending on the method of treatment and the effectiveness of the surgical intervention at these stages of small-cell lung carcinoma and preoperative chemotherapy in patients with process stages IIB, IIIA, and IIIB.

\section{MATERIALS AND METHODS.}

The study was based on the medical data of 852 patients with small-cell lung carcinoma that underwent treatment in the Altay regional oncologic center from 1995 to 2015.

The study protocol followed guidelines for experimental investigation with human subjects in accordance with the Declaration of Helsinki and was approved by the ethics committee. Written informed consent was obtained from each patient (or an official representative) before the study.

All patients were divided into 3 groups:

I. Without treatment $-155(18.2 \%)$ patients that declined treatment or that were refused treatment for medical reasons.

II. Conventional (Conservative) treatment - 558 (65.5\%) patients that received chemoradiotherapy treatment.

III. Surgical treatment $-139(16.3 \%)$ patients:

Subgroup I - surgery (without mediastinal lymph node dissection) - 31 (3.6\%) patients;

Subgroup II - surgery (without mediastinal lymph node dissection), 4 courses of postoperative polychemotherapy and distant radiotherapy, cumulative dose $50 \mathrm{~Gy}-81$ patients $(9.5 \%)$;

Subgroup III - 3-4 courses of preoperative polychemotherapy, mediastinal lymph node dissection, 2-4 courses of postoperative polychemotherapy - 27 patients (3.1\%). 
The study included 809 (94.9\%) men and 43 (5.1\%) women. The following age groups prevailed: $50-59$ years old -249 people $(29.2 \%)$ and $60-69$ years old -314 patients $(36.8 \%)$.

The majority of patients had stage IIIA (299 patients; 35.1\%), fewer patients had stage IIIB (194 patients, 22.7\%) (Table 1).

In Group I, there were fewer patients with stage IA than in Groups II and III. In Group II, there were more patients with stage IB than in Groups I and III. In Group II, 9.5\% of patients had stage IIB, $20.5 \%$ of patients had stage IIIA, and $7.4 \%$ of patients had stage IIIB, which was significantly more than in Groups I and III.

Among patients with stage IIB, there was a similar amount of patients with T2N1M0 and T3NOM0.

Among patients with IIIA, patients with T3N1M0 and T3N2M0 prevailed. Among patients with IIIB, patients with any TN3M0 were registered 2 times more often.

Metastases were revealed in 670 patients (78.6\%): 642 patients $(75.3 \%)$ had metastasis to regional lymph nodes and 28 patients (3.3\%) had remote metastasis.

Table 1. Stage of tumor process in patients with SCLC

\begin{tabular}{|c|c|c|c|c|c|c|c|c|c|c|c|c|}
\hline \multirow[t]{3}{*}{$\begin{array}{c}\text { Stag } \\
\text { e }\end{array}$} & \multirow[t]{3}{*}{ TNM } & \multicolumn{2}{|c|}{$\begin{array}{c}\text { All } \\
\text { patients }\end{array}$} & \multicolumn{9}{|c|}{ Group of patients } \\
\hline & & \multirow{2}{*}{$\begin{array}{c}\text { Abs. } \\
\text { numb } \\
\text { er }\end{array}$} & \multirow[t]{2}{*}{$\%$} & \multicolumn{2}{|c|}{ Group I } & \multicolumn{2}{|c|}{ Group II } & \multicolumn{2}{|c|}{ Group III } & \multirow[t]{2}{*}{ P1-2 } & \multirow[t]{2}{*}{ P1-3 } & \multirow[t]{2}{*}{ P2-3 } \\
\hline & & & & $\begin{array}{l}\text { Abs. } \\
\text { num } \\
\text { ber }\end{array}$ & $\%$ & $\begin{array}{l}\text { Abs. } \\
\text { num } \\
\text { ber }\end{array}$ & $\%$ & $\begin{array}{l}\text { Abs. } \\
\text { num } \\
\text { ber }\end{array}$ & $\%$ & & & \\
\hline IA & $\begin{array}{c}\mathrm{T}_{1} \mathrm{~N}_{0} \\
\mathrm{M}_{0}\end{array}$ & 56 & 6.5 & 12 & 1.4 & 23 & 2.7 & 21 & 2.4 & $\begin{array}{c}<0.00 \\
1\end{array}$ & $<0.01$ & $>0.05$ \\
\hline IB & $\begin{array}{c}\mathrm{T}_{2} \mathrm{~N}_{0} \\
\mathrm{M}_{0}\end{array}$ & 126 & 14.8 & 14 & 1.6 & 86 & $\begin{array}{c}10 . \\
1\end{array}$ & 26 & 3.0 & $\begin{array}{c}<0.00 \\
1\end{array}$ & $<0.01$ & $\begin{array}{l}<0.00 \\
1\end{array}$ \\
\hline IIA & $\begin{array}{c}\mathrm{T}_{1} \mathrm{~N}_{1} \\
\mathrm{M}_{0}\end{array}$ & 57 & 6.7 & 7 & 0,8 & 33 & 3,9 & 17 & 2,0 & $\begin{array}{c}<0.00 \\
1\end{array}$ & $\begin{array}{c}<0.00 \\
1\end{array}$ & $\begin{array}{l}<0.00 \\
1\end{array}$ \\
\hline \multirow[t]{3}{*}{ IIB } & $\begin{array}{c}\mathrm{T}_{2} \mathrm{~N}_{1} \\
\mathrm{M}_{0} \\
\end{array}$ & 105 & 12.3 & 4 & 0.5 & 88 & $\begin{array}{c}10 . \\
3 \\
\end{array}$ & 13 & 0.5 & $\begin{array}{c}<0.00 \\
1 \\
\end{array}$ & $\begin{array}{c}<0.00 \\
1\end{array}$ & $\begin{array}{l}<0.00 \\
1\end{array}$ \\
\hline & $\begin{array}{c}\mathrm{T}_{3} \mathrm{~N}_{0} \\
\mathrm{M}_{0}\end{array}$ & 89 & 10.4 & 3 & 0.3 & 78 & 9.1 & 8 & 0.9 & $\begin{array}{c}<0.00 \\
1\end{array}$ & $\begin{array}{c}<0.00 \\
1\end{array}$ & $\begin{array}{l}<0.00 \\
1\end{array}$ \\
\hline & Total & 194 & 22.7 & 7 & 0.8 & 166 & $\begin{array}{c}19 . \\
5\end{array}$ & 21 & 2.4 & $\begin{array}{c}<0.00 \\
1\end{array}$ & $\begin{array}{c}<0.00 \\
1\end{array}$ & $\begin{array}{l}<0.00 \\
1\end{array}$ \\
\hline \multirow[t]{5}{*}{ IIIA } & $\begin{array}{c}\mathrm{T}_{3} \mathrm{~N}_{1} \\
\mathrm{M}_{0}\end{array}$ & 88 & 10.3 & 18 & 2.1 & 58 & 6.8 & 12 & 1.4 & $\begin{array}{c}<0.00 \\
1\end{array}$ & $<0.05$ & $\begin{array}{l}<0.00 \\
1\end{array}$ \\
\hline & $\begin{array}{c}\mathrm{T}_{1} \mathrm{~N}_{2} \\
\mathrm{M}_{0} \\
\end{array}$ & 57 & 6.7 & 15 & 1.8 & 37 & 4.3 & 5 & 0.6 & $\begin{array}{c}<0.00 \\
1\end{array}$ & $\begin{array}{c}<0.00 \\
1\end{array}$ & $\begin{array}{l}<0.00 \\
1\end{array}$ \\
\hline & $\begin{array}{c}\mathrm{T}_{2} \mathrm{~N}_{2} \\
\mathrm{M}_{0}\end{array}$ & 68 & 8.0 & 28 & 3.3 & 34 & 4.0 & 6 & 0.7 & $>0.05$ & $\begin{array}{c}<0.00 \\
1\end{array}$ & $\begin{array}{l}<0.00 \\
1\end{array}$ \\
\hline & $\begin{array}{c}\mathrm{T}_{3} \mathrm{~N}_{2} \\
\mathrm{M}_{0}\end{array}$ & 86 & 10.1 & 16 & 1.8 & 46 & 5.4 & 24 & 2.8 & $\begin{array}{c}<0.00 \\
1\end{array}$ & $\begin{array}{c}<0.00 \\
2\end{array}$ & $\begin{array}{l}<0.00 \\
1\end{array}$ \\
\hline & Total & 299 & 35.1 & 77 & 9.0 & 175 & $\begin{array}{c}20 . \\
5\end{array}$ & 47 & 5.5 & $\begin{array}{c}<0.00 \\
1\end{array}$ & $<0.01$ & $\begin{array}{l}<0.00 \\
1\end{array}$ \\
\hline
\end{tabular}




\begin{tabular}{|c|c|c|c|c|c|c|c|c|c|c|c|c|}
\hline \multirow[t]{3}{*}{ IIIB } & $\begin{array}{l}\text { Any } \\
\mathrm{T} \\
\mathrm{N}_{3} \mathrm{M}_{0}\end{array}$ & 61 & 7.2 & 12 & 1.4 & 42 & 4.9 & 7 & 0.8 & $\begin{array}{c}<0.00 \\
1\end{array}$ & $<0.01$ & $\begin{array}{l}<0.00 \\
1\end{array}$ \\
\hline & $\begin{array}{l}\mathrm{T}_{4} \\
\text { any } \\
\mathrm{NM}_{0}\end{array}$ & 31 & 3.6 & 10 & 1.2 & 21 & 2.5 & - & - & $\begin{array}{c}<0.00 \\
1\end{array}$ & - & - \\
\hline & Total & 92 & 10.8 & 22 & 2.6 & 63 & 7.4 & 7 & 0.8 & $\begin{array}{c}<0.00 \\
1\end{array}$ & $<0.01$ & $\begin{array}{l}<0.00 \\
1\end{array}$ \\
\hline \multirow[t]{2}{*}{ IV } & $\begin{array}{l}\text { Any } \mathrm{T} \\
\text { any } \\
\mathrm{NM}_{1}\end{array}$ & 28 & 3.3 & 16 & 1.9 & 12 & 1.4 & - & - & $>0.05$ & - & - \\
\hline & Total & 852 & $\begin{array}{l}100 . \\
0\end{array}$ & 155 & $\begin{array}{c}18 . \\
2\end{array}$ & 558 & $\begin{array}{c}65 . \\
8 \\
\end{array}$ & 139 & 16.0 & $\begin{array}{c}<0.00 \\
1\end{array}$ & $>0.05$ & $\begin{array}{l}<0.00 \\
1\end{array}$ \\
\hline
\end{tabular}

\section{RESULTS.}

Life expectancy from 7 to 9 months in patients that received symptomatic therapy (Group I $18.1 \%$ ) and conventional treatment (Group II - 19.9\%) was similar (with insignificant deviations) $(\mathrm{P}<0.05)$. The same life expectancy in patients that received radical treatment (Group III) was registered in $83.4 \%$ of cases, which was $65.3 \%$ longer than in patients that received symptomatic treatment (Group I) $(<0.01)$ (the difference was statistically significant) and $63.5 \%$ longer than in patients that received conventional (Conservative) treatment (Group II). Life expectancy from 10 to 12 months was registered only in patients in Groups II and III (12.5\% and 67.6\%, respectively) $(<0.001)$. The difference between these groups remained during the period of observation. The difference became more evident in patients with life expectancy more than 24 months: in Group II in $1.8 \%$ of cases, which was less than in Group III by $34.2 \%$.

The longest average life expectancy was observed in patients from Group III (26.4 months), which was 19.6 months longer than in Group II and 24.2 months longer than in Group I (Table 2).

Table 2. Life expectancy in patients with SCLC depending on the treatment plan

\begin{tabular}{|c|c|c|c|c|c|c|c|c|c|}
\hline \multirow{3}{*}{$\begin{array}{l}\text { Life expectancy } \\
\quad \text { (months) }\end{array}$} & \multicolumn{6}{|c|}{ Groups of patients } & \multirow{2}{*}{\multicolumn{3}{|c|}{$\mathbf{P}$}} \\
\hline & \multicolumn{2}{|c|}{ Group I } & \multicolumn{2}{|c|}{ Group II } & \multicolumn{2}{|c|}{ Group III } & & & \\
\hline & $\begin{array}{l}\text { Abs. } \\
\text { numbe } \\
\text { r }\end{array}$ & $\%$ & $\begin{array}{l}\text { Abs. } \\
\text { numbe } \\
\text { r }\end{array}$ & $\%$ & $\begin{array}{l}\text { Abs. } \\
\text { numbe } \\
\text { r }\end{array}$ & $\%$ & P1-2 & P1-3 & P2-3 \\
\hline Up to 1 & 144 & 92.9 & 558 & 100.0 & 139 & 100.0 & $<0.05$ & $>0.05$ & $<0.05$ \\
\hline From 1 to 3 & 103 & 66.4 & 363 & 65.0 & 139 & 100.0 & $<0.05$ & $>0.05$ & $>0.05$ \\
\hline From 4 to 6 & 56 & 36.1 & 174 & 31.2 & 122 & 87.8 & $<0.05$ & $>0.05$ & $>0.05$ \\
\hline From 7 to 9 & 28 & 18.1 & 111 & 19.9 & 116 & 83.4 & $>0.05$ & $<0.01$ & $>0.05$ \\
\hline From 10 to 12 & - & - & 70 & 12.5 & 94 & 67.6 & - & - & $>0.05$ \\
\hline From 13 to 18 & - & - & 55 & 9.9 & 61 & 43.9 & - & - & $>0.05$ \\
\hline From 19 to 24 & - & - & 14 & 2.5 & 50 & 36.0 & - & - & $>0.05$ \\
\hline More than 24 & - & - & 10 & 1.8 & 50 & 36.0 & - & - & $>0.05$ \\
\hline TOTAL & 155 & 100.0 & 558 & 100.0 & 139 & 100.0 & - & - & $>0.05$ \\
\hline
\end{tabular}




\begin{tabular}{|c|c|c|c|c|}
\hline $\begin{array}{c}\text { Mean life } \\
\text { expectancy; X }\end{array}$ & 2.2 & 6.8 & 26.4 & \\
\hline
\end{tabular}

Mean (average) life expectancy in patients with SCLC directly correlates with the type of performed treatment. The inclusion of the surgical component increases the mean (average) life expectancy in by 12 times in comparison with patients who received symptomatic therapy and by 3.9 times in comparison with patients who received complex treatment.

The authors evaluated life expectancy in patients from Group III depending on the combination of surgery with other methods of treatment and the process stage. Patients were distributed into 3 subgroups: Subgroup I - surgical treatment only, Subgroup II - surgery in combination with postoperative chemoradiotherapy, and Subgroup III - preoperative polychemotherapy, surgery that included mediastinal lymph node dissection, and postoperative polychemotherapy (Table 3).

Table 3. Stage of tumor process in patients with SCLC that received radical therapy

\begin{tabular}{|c|c|c|c|c|c|c|c|c|c|c|}
\hline \multirow[t]{3}{*}{ Stage } & \multirow[t]{3}{*}{ TNM } & \multicolumn{6}{|c|}{ Group of patients } & \multicolumn{3}{|c|}{$\mathbf{P}$} \\
\hline & & \multicolumn{2}{|c|}{ Surgery } & \multicolumn{2}{|c|}{$\begin{array}{c}\text { Surgery with } \\
\text { chemoradiothera } \\
\text { py }\end{array}$} & \multicolumn{2}{|c|}{$\begin{array}{l}\text { Surgery with lymph } \\
\text { node dissection and } \\
\text { chemoradiotherapy }\end{array}$} & \multirow[t]{2}{*}{$\mathbf{P}_{1-2}$} & \multirow[t]{2}{*}{$\mathbf{P}_{1-3}$} & \multirow[t]{2}{*}{$\mathbf{P}_{2-3}$} \\
\hline & & $\begin{array}{l}\text { Abs. } \\
\text { number }\end{array}$ & $\%$ & $\begin{array}{l}\text { Abs. } \\
\text { number }\end{array}$ & $\%$ & $\begin{array}{l}\text { Abs. } \\
\text { number }\end{array}$ & $\%$ & & & \\
\hline IA & $\mathrm{T}_{1} \mathrm{~N}_{0} \mathrm{M}_{0}$ & 17 & 12.2 & 4 & 2.9 & - & - & $>0.05$ & - & - \\
\hline IB & $\mathrm{T}_{2} \mathrm{~N}_{0} \mathrm{M}_{0}$ & 14 & 10.1 & 12 & 8.6 & - & - & $>0.05$ & - & - \\
\hline IIA & $\mathrm{T}_{1} \mathrm{~N}_{1} \mathrm{M}_{0}$ & - & - & 17 & 12.2 & - & - & - & - & - \\
\hline \multirow[b]{2}{*}{ IIB } & $\mathrm{T}_{2} \mathrm{~N}_{1} \mathrm{M}_{0}$ & - & - & 13 & 9.3 & - & - & - & - & - \\
\hline & $\mathrm{T}_{3} \mathrm{~N}_{0} \mathrm{M}_{0}$ & - & - & 8 & 5.8 & - & - & - & - & - \\
\hline \multirow{4}{*}{ IIIA } & $\mathrm{T}_{3} \mathrm{~N}_{1} \mathrm{M}_{0}$ & - & - & 6 & 4.3 & 6 & 4.3 & - & - & $>0.05$ \\
\hline & $\mathrm{T}_{1} \mathrm{~N}_{2} \mathrm{M}_{0}$ & - & - & 5 & 3.6 & - & - & - & - & - \\
\hline & $\mathrm{T}_{2} \mathrm{~N}_{2} \mathrm{M}_{0}$ & - & - & 4 & 2.9 & 2 & 1.4 & - & - & $>0.05$ \\
\hline & $\mathrm{T}_{3} \mathrm{~N}_{2} \mathrm{M}_{0}$ & - & - & 12 & 8.6 & 12 & 8.6 & - & - & $>0.05$ \\
\hline \multirow[t]{2}{*}{ IIIB } & $\mathrm{T}_{3} \mathrm{~N}_{3} \mathrm{M}_{0}$ & - & - & - & - & 7 & 5.1 & - & - & - \\
\hline & Total & 31 & 22.3 & 81 & 58.3 & 27 & 19.4 & & & \\
\hline
\end{tabular}

Patients from Subgroup I with primary tumor process T1-2N0M0 (31 patients) received only surgical treatment. In patients with primary tumor process T1N0, life expectancy up to 6 months was registered in $100 \%$ of cases, which was by $14.3 \%$ longer than in patients with T2N0. Further observation showed that the difference in life expectancy from 7 to 12 months in these patients was statistically insignificant $(>0.05)$, and there were no patients whose life expectancy was more than 19 months.

The mean life expectancy in patients with stage T1N0 was 12.8 months, which was 4.3 months longer than in patients with T2N0 (Table 4). 
Table 4. Life expectancy in patients with SCLC with $\mathrm{N}_{0}$ that received surgical treatment depending on the degree (size) of the primary tumor

\begin{tabular}{|c|c|c|c|c|c|}
\hline \multirow{3}{*}{$\begin{array}{l}\text { Life expectancy } \\
\quad \text { (months) }\end{array}$} & \multicolumn{4}{|c|}{ Process stage $N_{0}$} & \multirow{3}{*}{$\begin{array}{c}\mathbf{P} \\
\mathbf{P}_{1-2}\end{array}$} \\
\hline & \multicolumn{2}{|c|}{$T_{1}(1)$} & \multicolumn{2}{|c|}{$T_{2}(2)$} & \\
\hline & $\begin{array}{l}\text { Abs. } \\
\text { number }\end{array}$ & $\%$ & $\begin{array}{l}\text { Abs. } \\
\text { number }\end{array}$ & $\%$ & \\
\hline Up to 1 & 17 & 100.0 & 14 & 100.0 & $>0.05$ \\
\hline From 1 to 3 & 17 & 100.0 & 14 & 100.0 & $>0.05$ \\
\hline From 4 to 6 & 17 & 100.0 & 12 & 85.7 & $>0.05$ \\
\hline From 7 to 9 & 10 & 58.8 & 7 & 50.0 & $>0.05$ \\
\hline From 10 to 12 & 5 & 29.4 & 5 & 35.7 & $>0.05$ \\
\hline From 13 to 18 & - & - & 1 & 7.1 & $>0.05$ \\
\hline From 19 to 24 & - & - & - & - & - \\
\hline More than 24 & - & - & - & - & - \\
\hline TOTAL & 17 & 100.0 & 14 & 100.0 & \\
\hline $\begin{array}{c}\text { Mean life } \\
\text { expectancy; X }\end{array}$ & \multicolumn{2}{|c|}{12.8} & \multicolumn{2}{|c|}{8.5} & \\
\hline
\end{tabular}

The authors evaluated life expectancy in patients from Subgroup II with lung tumor stage T1-3N0-2.

In patients with stage T1N0-2, life expectancy up to 9 months was observed in $100 \%$ of cases. In patients with T1N0-1, it remained to 12 months, in T1N0 - to 18 months, which was by $23.5 \%$ longer than in patients with $\mathrm{T} 1 \mathrm{~N} 1$ and by $40.0 \%$ than in patients with $\mathrm{T} 1 \mathrm{~N} 2$. Life expectancy from 19 to 24 months in patients with T1N0 was observed in $75.0 \%$ of cases, which was shorter by $1.5 \%$ than in patients with $\mathrm{T} 1 \mathrm{~N} 1(76.5 \%)$ and longer by $35.0 \%$ than in patients with T1N2. Life expectancy in patients with $\mathrm{T} 1 \mathrm{~N} 1$ was longer by $36.5 \%$ than in patients with $\mathrm{T} 1 \mathrm{~N} 2$ (the difference was statistically significant) $(<0.01)$. Life expectancy for more than 24 months was registered only in patients with T1N0-1; its ratio corresponded to a period of 19 to 24 months.

The mean (average) life expectancy in patients from this group is greatly influenced by metastases to the regional lymph nodes. Thus, the mean life expectancy in patients with T1N0 was 68.5 months, which was longer by 26.7 months or by 1.6 times than in patients with T1N1. Metastases to mediastinal lymph nodes (N2) reduced the mean life expectancy by 47.1 months or by 3.2 times in comparison with patients with T1N0 and by 20.4 months or 1.9 times in comparison with patients with T1N1 (Table 5).

Table 5. Life expectancy in patients with SCLC T1N0-2 that received surgical therapy in combination with chemoradiotherapy depending on the size of the primary tumor

\begin{tabular}{|c|c|c|c|c|c|c|c|c|c|}
\hline \multirow{3}{*}{$\begin{array}{l}\text { Life expectancy } \\
\text { (months) }\end{array}$} & \multicolumn{6}{|c|}{ Process stage $\mathrm{T}_{1}$} & \multirow{2}{*}{\multicolumn{3}{|c|}{$\mathbf{P}$}} \\
\hline & \multicolumn{2}{|c|}{$\mathrm{N}_{0}(\mathbf{1})$} & \multicolumn{2}{|c|}{$\mathrm{N}_{1}(2)$} & \multicolumn{2}{|c|}{$\mathbf{N}_{2}(3)$} & & & \\
\hline & $\begin{array}{l}\text { Abs. } \\
\text { numb }\end{array}$ & $\%$ & $\begin{array}{l}\text { Abs. } \\
\text { numb }\end{array}$ & $\%$ & $\begin{array}{l}\text { Abs. } \\
\text { numb }\end{array}$ & $\%$ & $\mathbf{P}_{1-2}$ & $\mathbf{P}_{1-3}$ & $\mathbf{P}_{2-3}$ \\
\hline
\end{tabular}




\begin{tabular}{|l|l|l|l|l|l|l|l|l|l|}
\cline { 2 - 11 } & er & & er & & er & & & & \\
\hline Up to 1 & 4 & 100.0 & 17 & 100.0 & 5 & 100.0 & $>0.05$ & $>0.05$ & $>0.05$ \\
\hline From 1 to 3 & 4 & 100.0 & 17 & 100.0 & 5 & 100.0 & $>0.05$ & $>0.05$ & $>0.05$ \\
\hline From 4 to 6 & 4 & 100.0 & 17 & 100.0 & 5 & 100.0 & $>0.05$ & $>0.05$ & $>0.05$ \\
\hline From 7 to 9 & 4 & 100.0 & 17 & 100.0 & 5 & 100.0 & $>0.05$ & $>0.05$ & $>0.05$ \\
\hline From 10 to 12 & 4 & 100.0 & 17 & 100.0 & 4 & 80.0 & $>0.05$ & $>0.05$ & $>0.05$ \\
\hline From 13 to 18 & 4 & 100.0 & 13 & 76.5 & 3 & 60.0 & $>0.05$ & $>0.05$ & $>0.05$ \\
\hline From 19 to 24 & 3 & 75.0 & 13 & 76.5 & 2 & 40.0 & $>0.05$ & $<0.01$ & $<0.01$ \\
\hline More than 24 & 3 & 75.0 & 13 & 76.5 & - & - & $>0.05$ & - & - \\
\hline TOTAL & 4 & 100.0 & 17 & 100.0 & 5 & 100.0 & $>0.05$ & $>0.05$ & $>0.05$ \\
\hline $\begin{array}{c}\text { Mean life } \\
\text { expectancy; X }\end{array}$ & \multicolumn{2}{|c|}{68.5} & & & & & & \\
\end{tabular}

Life expectancy in patients with primary lung tumor T1 is greatly influenced by metastasis to the regional lymph nodes, especially, mediastinal lymph nodes. In patients with $\mathrm{N} 2$, the mean (average) life expectancy was shorter by 3.2 times than in patients with N0 and by 1.9 times than in patients with N1.

In patients with primary tumor stage T2N0-2, life expectancy up to 6 months was registered in $100 \%$ of cases and it remained in patients with T2N0 and T2N2 up to 9 months, which was longer than in patients with $\mathrm{T} 2 \mathrm{~N} 1$ by $7.7 \%$. Up to 12 months, $100 \%$ survival was observed in patients with $\mathrm{T} 2 \mathrm{~N} 0$, which was higher by $32.1 \%$ than in patients with $\mathrm{T} 2 \mathrm{~N} 1$ and by $50.0 \%$ than in patients with T2N2. It should be mentioned that there was a difference in life expectancy from 19 to 24 months between patients with N1 and N0. Patients with T2N1 had this life expectancy in 69.2\% of cases, which was by $2.6 \%$ longer than in patients with $\mathrm{T} 2 \mathrm{~N} 0$ and by $44.2 \%$ longer than in patients with T2N2. In percent ratio, life expectancy for more than 24 months was comparable with previous values in patients with $\mathrm{T} 2 \mathrm{~N} 1$ and $\mathrm{T} 2 \mathrm{~N} 2$. In patients with $\mathrm{T} 2 \mathrm{~N} 0$, it was registered in $50.0 \%$ of cases, which was shorter by $19.2 \%$ than in patients with $\mathrm{T} 2 \mathrm{~N} 1$ and was longer by $25.0 \%$ than in patients with $\mathrm{T} 2 \mathrm{~N} 2 \%$.

The longest life expectancy was observed in patients with T2N0 - 29.3 months, which was longer by 4.8 months than in patients with $\mathrm{T} 2 \mathrm{~N} 1$ and by 10.8 than in patients with $\mathrm{T} 2 \mathrm{~N} 2$ (Table 6 ).

Table 6. Life expectancy in patients with SCLC T2N0-2 that received surgical treatment in combination with chemoradiotherapy depending on the size of the primary tumor

\begin{tabular}{|c|c|c|c|c|c|c|c|c|c|}
\hline \multirow{3}{*}{$\begin{array}{l}\text { Life expectancy } \\
\quad \text { (months) }\end{array}$} & \multicolumn{6}{|c|}{$\overline{\text { Process stage }}_{2}$} & \multirow{2}{*}{\multicolumn{3}{|c|}{$\mathbf{P}$}} \\
\hline & \multicolumn{2}{|c|}{$\mathbf{N}_{0}(\mathbf{1})$} & \multicolumn{2}{|c|}{$N_{1}(2)$} & \multicolumn{2}{|c|}{$\mathbf{N}_{2}(3)$} & & & \\
\hline & $\begin{array}{l}\text { Abs. } \\
\text { numb } \\
\text { er }\end{array}$ & $\%$ & $\begin{array}{l}\text { Abs. } \\
\text { numb } \\
\text { er }\end{array}$ & $\%$ & $\begin{array}{l}\text { Abs. } \\
\text { numb } \\
\text { er }\end{array}$ & $\%$ & $\mathbf{P}_{1-2}$ & $\mathbf{P}_{1-3}$ & $\mathbf{P}_{2-3}$ \\
\hline Up to 1 & 12 & 100.0 & 13 & 100.0 & 4 & 100.0 & $>0.05$ & $>0.05$ & $>0.05$ \\
\hline From 1 to 3 & 12 & 100.0 & 13 & 100.0 & 4 & 100.0 & $>0.05$ & $>0.05$ & $>0.05$ \\
\hline From 4 to 6 & 12 & 100.0 & 13 & 100.0 & 4 & 100.0 & $>0.05$ & $>0.05$ & $>0.05$ \\
\hline From 7 to 9 & 12 & 100.0 & 12 & 92.3 & 4 & 100.0 & $>0.05$ & $>0.05$ & $>0.05$ \\
\hline
\end{tabular}




\begin{tabular}{|l|c|c|c|c|c|c|c|c|c|}
\hline From 10 to 12 & 12 & 100.0 & 10 & 76.9 & 2 & 50.0 & $>0.05$ & $>0.05$ & $>0.05$ \\
\hline From 13 to 18 & 10 & 83.3 & 9 & 69.2 & 2 & 50.0 & $>0.05$ & $>0.05$ & $>0.05$ \\
\hline From 19 to 24 & 8 & 66.6 & 9 & 69.2 & 1 & 25.0 & $>0.05$ & $>0.05$ & $>0.05$ \\
\hline More than 24 & 6 & 50.0 & 9 & 69.2 & 1 & 25.0 & $>0.05$ & $>0.05$ & $>0.05$ \\
\hline TOTAL & 12 & 100.0 & 13 & 100.0 & 4 & 100.0 & $>0.05$ & $>0.05$ & $>0.05$ \\
\hline $\begin{array}{c}\text { Mean life } \\
\text { expectancy; X }\end{array}$ & \multicolumn{2}{|c|}{29.3} & \multicolumn{2}{|c|}{18.5} & & & \\
& & & & & & & \\
\hline
\end{tabular}

It can be seen that metastasis to regional lymph nodes in patients with $\mathrm{T} 2$ has a less significant influence than the size of the primary tumor in the lung. In patients with metastasis to regional lymph nodes $\mathrm{N} 1$, the mean life expectancy can be shorter by 1.2 times than in patients with N0 and longer by 1.3 times than in patients with N3. Mean (average)) life expectancy in patients with $\mathrm{N} 0$ is longer by 1.6 times than in patients with $\mathrm{N} 2$.

All patients with primary lung tumor process T3N0-2 had life expectancy up to 3 months in $100 \%$ of cases. Significant differences in this group of patients start to appear within the period from 10 to 12 months. Life expectancy in patients with T3N0 was $75.0 \%$, which was by $25.0 \%$ longer than in patients with $\mathrm{T} 3 \mathrm{~N} 1$ and by $41.7 \%$ than in patients with $\mathrm{T} 3 \mathrm{~N} 2$. The longest life expectancy (more than 24 months) was observed in patients with tumor stage T3N0 (in $25.0 \%$ of patients), which was by $8.3 \%$ longer than in patients with $\mathrm{T} 3 \mathrm{~N} 1$ and by $16.7 \%$ longer than in patients with T3N2 (the differences were statistically significant).

Mean life expectancy in patients with T3N0 was 19.4 months, which was by 3 months longer than in patients with T3N1 and by 9 months longer than in patients with T3N2 (Table 7).

Table 7. Life expectancy in patients with SCLC T3N0-2 that received surgical treatment in combination with chemoradiotherapy depending on the size of the primary tumor

\begin{tabular}{|c|c|c|c|c|c|c|c|c|c|}
\hline \multirow{3}{*}{$\begin{array}{l}\text { Life expectancy } \\
\quad \text { (months) }\end{array}$} & \multicolumn{6}{|c|}{${\text { Process stage } \mathbf{T}_{3}}$} & \multirow{2}{*}{\multicolumn{3}{|c|}{$\mathbf{P}$}} \\
\hline & \multicolumn{2}{|c|}{$\mathrm{N}_{0}(1)$} & \multicolumn{2}{|c|}{$\mathrm{N}_{1}(2)$} & \multicolumn{2}{|c|}{$\mathbf{N}_{2}(3)$} & & & \\
\hline & $\begin{array}{l}\text { Abs. } \\
\text { numb } \\
\text { er }\end{array}$ & $\%$ & $\begin{array}{l}\text { Abs. } \\
\text { numb } \\
\text { er }\end{array}$ & $\%$ & $\begin{array}{l}\text { Abs. } \\
\text { numb } \\
\text { er }\end{array}$ & $\%$ & $\mathbf{P}_{1-2}$ & $\mathbf{P}_{1-3}$ & $\mathbf{P}_{2-3}$ \\
\hline Up to 1 & 8 & 100.0 & 6 & 100.0 & 12 & 100.0 & $>0.05$ & $>0.05$ & $>0.05$ \\
\hline From 1 to 3 & 8 & 100.0 & 6 & 100.0 & 12 & 100.0 & $>0.05$ & $>0.05$ & $>0.05$ \\
\hline From 4 to 6 & 8 & 100.0 & 5 & 83.3 & 11 & 91.7 & $>0.05$ & $>0.05$ & $>0.05$ \\
\hline From 7 to 9 & 7 & 87.5 & 5 & 83.3 & 9 & 75.0 & $>0.05$ & $>0.05$ & $>0.05$ \\
\hline From 10 to 12 & 6 & 75.0 & 3 & 50.0 & 4 & 33.3 & $>0.05$ & $>0.05$ & $>0.05$ \\
\hline From 13 to 18 & 4 & 50.0 & 3 & 50.0 & 3 & 25.0 & $>0.05$ & $>0.05$ & $>0.05$ \\
\hline From 19 to 24 & 2 & 25.0 & 2 & 33.3 & 2 & 16.7 & $>0.05$ & $>0.05$ & $>0.05$ \\
\hline More than 24 & 2 & 25.0 & 1 & 16.7 & 1 & 8.3 & $>0.05$ & $>0.05$ & $>0.05$ \\
\hline TOTAL & 8 & 100.0 & 6 & 100.0 & 12 & 100.0 & & & \\
\hline $\begin{array}{c}\text { Mean life } \\
\text { expectancy; X }\end{array}$ & \multicolumn{2}{|c|}{19.4} & \multicolumn{2}{|c|}{16.4} & \multicolumn{2}{|c|}{10.4} & & & \\
\hline
\end{tabular}

Life expectancy in patients with T3N0-2 is significantly influenced by the size of the 
primary tumor and metastasis to mediastinal lymph nodes, which is confirmed by the data on the mean life expectancy. In patients with T3N0, it is longer by 1.9 times than in patients with T3N2 and by 1.2 times than in patients with T3N1. The difference between T3N1 and T3N2 was 1.6 times.

The analysis of life expectancy in patients with lung tumor stage T1-3N0-2 showed that there was a correlation between the mean (average) life expectancy and the size of the primary tumor, especially in patients with N0. In patients with primary tumor T1N0, life expectancy was 68.5 months, which was longer by 39.2 months than in patients with T2N0 and by 49.1 months longer than in patients with T3N0. The differences between patients with T2N0 (29.3) and T3N0 (19.4) were less significant (only 9.9 months). This correlation between the mean (average) life expectancy and the size of the primary tumor remains in patients with T1N1 (41.8 months), which was longer by 17.3 months than in patients with T2N1 and by 25.4 months in patients with T3N1. In patients with $\mathrm{T} 2 \mathrm{~N} 1$, the mean life expectancy was longer by 8.1 months than in patients with T3N1.

Metastases to regional lymph nodes actively influenced the mean (average) life expectancy in patients with tumor stage T2-3N1-2. In patients with T2N1, the mean (average) life expectancy was 24.5 months, which was 6.0 months longer than in patients with T2N2 and by 8.1 months than in patients with T3N1. The difference in the mean life expectancy between patients with T3N1 (16.4) and with T3N2 (10.4) was 6.0 months, which was the same as between patients with T2N1 and T2N2. Between patients with T2N2 and T3N2, it was 8.1 months.

The observation of patients with tumor stages IIB, IIIA and IIIB that underwent (who had undergone) surgical treatment in combination with postoperative chemoradiotherapy revealed that $19.8 \%$ of patients had early recurrence to regional lymph nodes (mediastinal and supraclavicular lymph nodes) 7 months after the beginning of the therapy, and this tendency increased with the elongation of life expectancy of patients. Within the period of 10 to 12 months, the recurrence was registered in $65.8 \%$ of patients, which reduced the mean life expectancy of patients.

Taking into account the above-mentioned facts, the authors selected patients with tumor stages IIIA and IIIB for surgical treatment. The first stage of therapy included 3-4 courses of chemotherapy with further evaluation of the therapy effectiveness (chest X-ray, mediastinal MRI, USI of supraclavicular region and neck). When the regression of tumor was $50 \%$ and more, surgical treatment was performed that included pulmonectomy with mediastinal lymph nodes dissection (27 patients, $100.0 \%)$. In 7 patients $(25.9 \%)$ with metastases to supraclavicular lymph nodes and neck, one step extended pulmonectomy with mediastinal lymph nodes dissection and radical neck excision on the side of the tumor were performed. During the observation period, the recurrence in the area of surgery was not registered. Postoperative histologic material obtained from the primary tumor was used for the pathomorphological study. In 9 patients $(33.3 \%)$, tumor pathomorphism of the 2nd-3rd degree was revealed, which allowed the authors to indicate these patients 2 courses of 
chemotherapy analogic to the pre-operative courses. When tumor pathomorphism was lower than the 2nd-3rd degree, 4 courses of chemotherapy with reserve-line drugs were performed in the postoperative period. These patients had tumor recurrence in the supraclavicular lymph nodes in 2 cases $(7.4 \%)$ within the period from 19 to 24 months, which provided grounds for radical excision of the neck. Because of complete lymph node dissection, these patients were not indicated remote radiotherapy in the postoperative period and this did not affect the quality of therapy.

Mean (average) life expectancy in this group of patients (Subgroup III) was 29.6 months, which corresponded to the mean (average) life expectancy in patients from Subgroup II with tumor stage T2N0 (29.3 months).

\section{CONCLUSIONS.}

The surgical method of treatment for small-cell lung carcinoma positively influenced the mean (average) life expectancy in patients from Group III. It was 26.4 months, which was longer than in Group II by 19.6 months and in Group I by 24.2 months.

The size of the primary tumor in the lung began to influence the mean life expectancy in patients with tumor stage T1-2 and metastasis to regional lymph nodes - in patients with T2-3N1-2.

The selection of patients with tumor stages IIIA and IIIB for surgical treatment with preoperative chemotherapy and obligatory inclusion of mediastinal lymph dissection provided mean life expectancy in Subgroup III similar to the mean life expectancy in patients from Group II with IIA (T2N0).

\section{FINANCIAL SUPPORT AND SPONSORSHIP}

Nil.

\section{CONFLICTS OF INTEREST}

The authors declare no conflict of interest

SUPPLEMENTARY DATA (DOI)

\section{REFERENCES}

1. Moiseev P.I. Combined treatment of patients with small cell lung cancer using postoperative chemotherapy and preventive brain radiation [Kombinirovannoe lechenie bol'nykh melkokletochnym rakom legkogo $\mathrm{s}$ ispol'zovaniem posleoperatsionnoi khimioterapii i profilakticheskogo oblucheniia golovnogo mozga] Cancer journal - Onkologicheskii zhurnal, 2009, vol. 3, no 1(9), pp. 21-25.

2. Moiseev P.I., Zharkov V.V. Role of surgery in combined treatment of patients with small cell lung cancer: own experience. [Rol' khirurgii v kombinirovannom lechenii bol'nykh melkokletochnym rakom legkogo: sobstvennyi opyt] Cancer journal - Onkologicheskii zhurnal, 2007, vol. 1, no 1, pp. $1-17$. 
3. Karrer K. Correlation of intensity of adjuvant chemotherapy after surgery for cure for lung cancer on survival time. Proceedings of the Second Mediterranean Congress on Thoracic Disease (Athens, Greece, March 1998), 1998, pp. 17-20.

4. Zinchenko S.V. The role of the surgical component in the treatment of small cell lung cancer: Abstract of the dissertation of the candidate of medical sciences [Rol' khirurgicheskogo komponenta $\mathrm{v}$ lechenii melkokletochnogo raka legkogo: Avtoreferat dissertatsii kandidata meditsinskikh nauk]. Moscow, 2005, 22 p.

5. Chernykh A.V. Perfection of a surgical method of treatment of patients with lung cancer: the dissertation of a doctor of medical sciences [Sovershenstvovanie khirurgicheskogo metoda lecheniia bol'nykh rakom legkogo: dissertatsiia doktora meditsinskikh nauk]. Ryazan, 2010, 223 p

6. Sushko A.A., Savitskii S.E., Mozheiko M.A. et al. Surgical treatment of lung cancer [Khirurgicheskoe lechenie raka legkogo]. Journal of the Grodno State Medical UniversityZhurnal Grodnenskogo gosudarstvennogo meditsinskogo universiteta, 2011, no 2, pp. 65-67.

7. Kolbanov K.I., Trakhtenberg A.Kh., Pikin O.V. Possibilities of surgery for resectable small cell lung cancer. [Vozmozhnosti khirurgii pri rezektabel'nom melkokletochnom rake legkogo]. Herzen Journal of Oncology - Onkologiya. Zhurnal imeni P.A. Gertsena, 2017, vol. 6, no 3, pp. 67-75.

8. Ramazanova M.S., Kislichko A.G. Small cell lung cancer: effectiveness of different treatment regimens, long-term results and prognosis [Melkokletochnyi rak legkikh: effektivnost' razlichnykh skhem lecheniia, otdalennye rezul'taty i prognoz]. Kazan Medical Journal - Kazanskii meditsinskii zhurnal, 2012, vol. 93, no 4, pp. 623-627.

9. Fokeev S.D., Kazantseva E.S., Maksimenko A.A. The importance of surgery in the complex treatment of small cell lung cancer $\mathrm{t}_{3} \mathrm{n}_{0-3} \mathrm{~m}_{0}$ [Mesto khirurgicheskogo komponenta $\mathrm{v}$ kompleksnom lechenii melkokletochnogo raka legkogo $\mathrm{T}_{3} \mathrm{~N}_{0-3} \mathrm{M}_{0}$. Modern problems of science and education Sovremennye problemy nauki $i$ obrazovanii-, 2017, no. 5, available at: http://www.scienceeducation.ru/ru/article/view?id=26959. (accessed 27.03.2019).

10. Fokeev S.D., Kazantseva E.S. Method of treating patients with localized small cell lung cancer $\mathrm{t}_{3} \mathrm{n}_{0-3}$ $\mathrm{m}_{0}$. Patent of the Russian Federation [Sposob lecheniia bol'nykh s lokalizovannym melkokletochnym rakom legkogo $\mathrm{T}_{3} \mathrm{~N}_{0-3} \mathrm{M}_{0}$. Patent Rossiiskoi Federatsii], № 2342078, 2012 